\title{
HUBUNGAN PRESTASI AKADEMIK DENGAN KECEMASAN ALUMNI DALAM MENGHADAPI UJI KOMPETENSI NERS DI STIKES MUHAMMADIYAH LAMONGAN
}

\author{
Dadang Kusbiantoro \\ Program Studi S1 Keperawatan STIKES Muhammadiyah Lamongan \\ Email : virgianti_nf@yahoo.com
}

\begin{abstract}
Anxiety is an uncertainty of fear, associated with feelings of doubt or helplessness. The implementation of UKNI was left as an increasing burden for alumni. Preparing to take the UKNI exam can cause anxiety and if you cannot adjust the conditions to the problem will feel anxious and helpess.The study aim to know the correlation of academic achievement with alumni anxiety in Ners competency test at STIKes Muhammadiyah Lamongan. The study design used Analytic correlation design with cross sectional. The population of 64 people with sample 55 through the calculation of simple Rondom Sampling. The data accumulated with closed questionnaire and analyzed using Spearman Rank test on SPSS 18.0 program with significance level $\alpha=0.05$. The results showed that almost all alumni had satisfactory academic achievement (78.18\%), almost half of alumni had moderate anxiety (36,36\%). Based on Spearman Rank test result $p=0,866(p>0,05)$ which means there is no correlation between academic achievement with alumni anxiety in Ners competency test at STIKes Muhammadiyah Lamongan. In this study showed the anxiety experienced by the alumni was not influenced causeof academic achievement, but there are may other factors can cause affected the anxiety itself.
\end{abstract}

Keyword: Academic Achievement, Anxiety, Ners Competency Test

\section{PENDAHULUAN}

Tenaga kesehatan merupakan salah satu faktor terpenting dalam mendukung fungsi sistem pelayanan kesehatan.Dibutuhkan tenaga kesehatan yang kompeten dan berdedikasi dalam jumlah dan sebaran yang baik untuk dapat menjalankan peran dan fungsinya secara optimal.Peningkatan kualitas pendidikan tenaga kesehatan adalah salah satu langkah strategis untuk meningkatkan ketersediaan tenaga kesehatan berkualitas danmemiliki kompetensi yang relevan untuk menjalankan sistem pelayanankesehatan.Salah satu upaya untuk mendorong percepatan peningkatandan pemerataan kualitas pendidikan tenaga kesehatan adalah dengan meningkatkan kendali mutu lulusan pendidikan.Sebagai profesi, keperawatan dituntut untuk memiliki kemampuan intelektual, interpersonal kemampuan teknis dan moral.Hal ini dapat ditempuh dengan meningkatkan kualitas perawat melalui pendidikan lanjutan pada Program Pendidikan Profesi Ners. Upaya untuk lebih mengembangkan pendidikan keperawatan profesional 
sudah dilakukan mulai dari Akademi Keperawatan diharapkan dapat melanjutkan ke jenjang Sarjana Keperawatan (Ners).

Untuk menghasilkan seorang perawat profesional, harus melewati dua tahap pendidikan yaitu tahap pendidikan akademik yang lulusannya mendapat gelar sarjana keperawatan (S.Kep) dan tahap pendidikan profesi yang lulusannya mendapat gelar Ners (Ns). Kedua tahap pendidikan keperawatan ini harus diikuti, karena keduanya merupakan tahapan pendidikan yang terintegrasi sehingga tidak dapat dipisahkan antara satu sama lain. Pada tahap akademik mahasiswa mendapatkan teori-teori dan konsep-konsep.Mata kuliah pada tahap ini terbagi menjadi kelompok mata kuliah yang sifatnya umum, mata kuliah penunjang seperti mata kuliah medis yang secara tidak langsung menunjang mata kuliah keperawatan dan mata kuliah keahlian berupa mata kuliah keperawatan.Sedangkan pada tahap pendidikan profesi mahasiswa mengaplikasikan teori-teori dan konsep-konsep yang telah didapat selama tahap akademik. Setelah pendidikan profesi tahap selanjutnya melakukan UKNI.

Pelaksanaan UKNI dirasakan sebagai beban yang semakin bertambah berat terutama bagi alumni. UKNI menjadi perhatian bagi alumni, dikarenakan apabila tidak lulus UKNI maka tidak dapat mengikuti wisudah dan tidak akan teregistrasi untuk menjadi calon perawat di wilayah indonesia, sehingga menyebabkan timbulnya perasaan khawatir, takut, tegang, cemas serta adanya tekanan pada diri alumni.

Data kelulusan UKNI berdasarkan RISTEKDIKTI 2015 bahwa pada bulan Juli tahun 2014 mencapai 57, 81 \%, sedangkan pada bulan November 2014 persentase mahasiswa yang lulus menurunmenjadi 46,2 \%. Tahun 2015 periode IV persentase kelulusan peserta UKNI mencapai 56\%, pada bulan November 2016 mencapai $53,61 \%$. Sedangkan hasil lulusan UKNI Stikes Muhammadiyah Lamongan pada bulan November 2017 didapatkan hasil lulusan UKNI pada tanggal 12 Oktober 2015 dari 174 alumni yang mengikutu ujian, 53,4\% memenuhi standar kompetensi dan 46,6\% tidak memenuhi standar kompetensi. Pada tanggal 8 November 2016 dari 176 alumni yang mengikutu ujian, 39,8\% memenuhi standar kompetensi dan 60,2\% tidak memenuhi standar kompetensi. Pada tanggal 27 April 2017 dari 183 alumni yang mengikuti ujian, 52,5\% memenuhi standar kompetensi dan 47,5\%tidak memenuhi standar kompetensi. Pada tanggal 22 Agustus 2017 dari 239 alumni yang mengikuti ujian, 54,4\% memenuhi standar kompetensi dan 45,6\%tidak memenuhi standar kompetensi.

Dari hasil studi pendahuluan yang dilakukan Dan pada tanggal 24 November 2017 dari 105 alumni yang mengikuti ujian, 12,38\% memenuhi standar kompetensi dan 87,62\%tidak memenuhi standar kompetensi. Dari 10 alumni Stikes Muhammadiyah Lamongan yang pernah mengikuti UKNI didapatkan hasil, 7 alumni mengalami kecemasan sedang dan 3 alumni mengalami kecemasan ringan.Berdasarkan data dan fenomena di atas peneliti tertarik untuk melakukan 
penelitian tentang masih tingginya kecemasan alumni Stikes Muhammadiyah Lamongan dalam menghadapi UKNI.

Mempersiapkan diri untuk mengikuti ujian UKNI dapat menimbulkan kecemasan, ditambah rendahnya presentase kelulusan pada UKNI tanggal 24 November 2017 dapat membuat alumni menjadi down. Apabila alumni tidak dapat menyesuaikan kondisi terhadap masalah tersebut akan merasa cemas dan tidak berdaya.Hal ini di karenakan pernah tidak lulus pada kesempatan sebelumnya, kurangnya persiapan, prestasi akademik yang rendah serta masalah kesehatan merupakan dampak dari faktor cemas dalam menghadapi Uji Kompetensi ners.

Kecemasan merupakan sifat ketakutan yang tidak pasti, berhubungan dengan perasaan ragu ragu atau tidak berdaya. Perasaan kecemasan begitu umum dirasakan oleh masyarakat,termasuk alumni. Kecemasan melibatkan respon tubuh, persepsi diri, dan hubungan dengan orang lain. Kecemasan akan menjadi masalah ketika individu tidak dapat mencegah peningkatan kecemasan tersebut (Townsend, 2005).

Menurut Goff, (2011) kecemasan tingkat tinggi pada alumni keperawatan dapat mempengaruhi memori, konsentrasi, dan kemampuan pemecahan masalah, dan dapat menyebabkan belajar menurun, dan kinerja akademik menurun. Oleh karena itu tingkat stres tinggi dapat memiliki dampak buruk dalam menghadapi uji kompetensi.

Untuk itu, UKNI perlu dihadapi dengan serius sejak masa pendaftaran hingga saat mengerjakan soal tes. Dalam masa pendaftaran, mungkin anda tidak akan terlalu repot karena semua sudah dikoordinasi oleh institusi. Tetapi mahasiswa harus memfokuskan pikiran pada persiapan materi dan mental untuk menghadapi UKNI. Masa persiapan yang dapat dilakukan oleh mahasiswa sebelum tes UKNI meliputi belajar tentang materi tes yang akan di uji, membentuk kelompok diskusi, mengikuti try out yang diadakan oleh institusi, atau sejak tahap akademik dapat mempersiapkan diri dengan baik, dan yang terpenting selalu meminta do'a kepada Allah SWT dan orang tua (Adiwidya, 2015).

Tujuan penelitian ini adalah untuk mengetahui hubungan prestasi akademik dengan kecemasanalumni dalam menghadapi uji kompetensi NersSekolah Tinggi Ilmu Kesehatan Muhammadiyah Lamongan.

\section{METODE PENELITIAN}

Desain penelitian yang digunakan dalam penelitian ini adalah penelitian analitik.Dalam hal ini metode penelitian yang digunakan adalah metode korelasi dengan pendekatan Cross Sectional. Sampel pada penelitian ini adalah Sebagian alumni Stikes Muhammadiyah Lamongan yang mengikuti uji kompetensi ners bulan Januari-Maret 2018 Berjumlah 55 alumni. Teknik pengambilan sampel dalam penelitian ini menggunakan simple rondom sampling yaitu pemilihan sampling yang diseleksi secara acak (Setiadi, 2013). Instrumen yang digunakan pada penelitian ini adalah lembar observasi, dan kuisioner. 


\section{HASIL DAN PEMBAHASAN}

Tabel 1 Distribusi frekuensi jenis kelamin di Stikes Muhammadiyah Lamongan.

\begin{tabular}{lcc}
\multicolumn{1}{c}{ Umur } & Frekuensi & Persentasi (\%) \\
\hline Laki-Laki & 28 & 50,9 \\
Perempuan & 27 & 49,1 \\
\hline Jumlah & 55 & 100 \\
\hline
\end{tabular}

Dari tabel 1 dapat dijelaskan bahwa sebagian besar $(50,9 \%)$ dari alumni berjenis kelamin laki-laki.

Tabel 2 Distribusi Frekuensi Berapa Kali Ikut UKNI di STIKes Muhammadiyah Lamongan.

\begin{tabular}{lcc}
\hline \multicolumn{1}{c}{ Frekuensi Ikut UKNI } & Jumlah & Persentase \\
\hline 2 kali & 34 & 61,8 \\
3 kali & 10 & 18,2 \\
>3 kali & 11 & 20,0 \\
\hline Jumlah & 55 & 100 \\
\hline
\end{tabular}

Dari tabel 2 dapat dijelaskan bahwa sebagian besar $(61,8 \%)$ dari alumni telah mengikuti UKNI sebanyak 2 kali.

Tabel 3 Distribusi Prestasi Akademik dengan Kecemasan Alumni dalam Menghadapi Uji Kompetensi Ners Di STIKes Muhammadiyah Lamongan.

\begin{tabular}{lcc}
\hline Prestasi Akademik & Jumlah & Persen \\
\hline Terpuji & 12 & 21,82 \\
Sangat Memuaskan & 43 & 78,18 \\
Memuaskan & 0 & 0 \\
\hline Jumlah & 55 & 100 \\
\hline
\end{tabular}

Dari tabel 3 menunjukkan bahwa hampir seluruh (78,18\%) alumni memiliki prestasi akademik sangat memuaskan.

Tabel 4 Distribusi Frekuensi Kecemasan Alumni Dalam Menghadapi Ners Bulan Maret 2018

\begin{tabular}{lll}
\hline Kecemasan & Jumlah & Persen \\
\hline Tidak cemas & 11 & 20 \\
Cemas ringan & 18 & 32,73 \\
Cemas sedang & 20 & 36,36 \\
Cemas berat & 6 & 10,91 \\
\hline Jumlah & 55 & 100 \\
\hline
\end{tabular}

Dari tabel 4 didapatkan hasil hampir setengah (36,36\%) alumni mengalami kecemasan sedang dan sebagian kecil $(10,91 \%)$ alumni mengalami kecemasan berat. 
Tabel 5 Tabel distribusi silang prestasi akademik dengan tingkat kecemasan alumni dalam Menghadapi Ners di STIKes Muhammadiyah Lamongan 2018 .

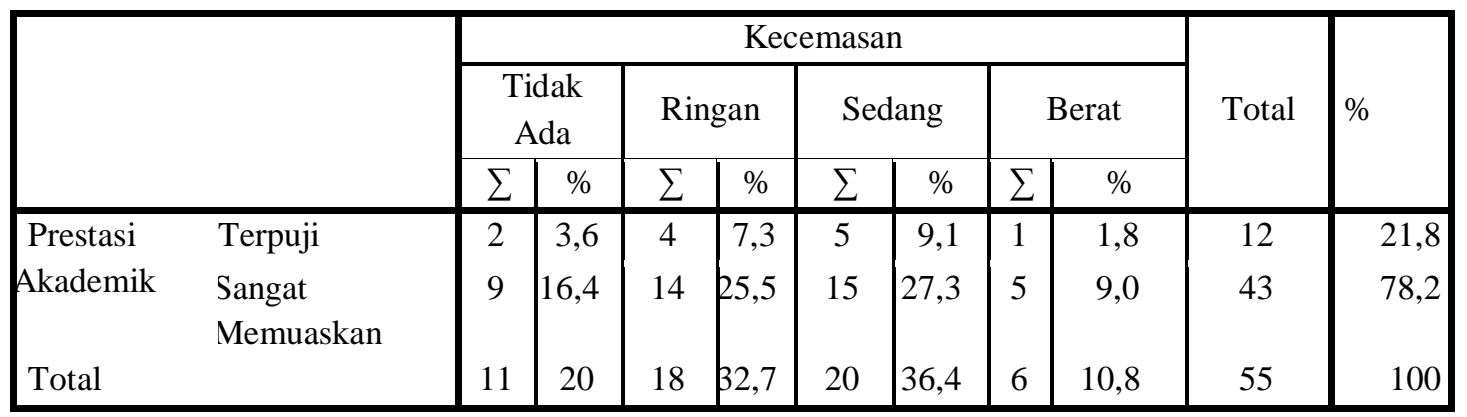

Berdasarkan tabel 5 menunjukkan hampir seluruh $(78,18 \%)$ alumni memiliki prestasi akademik sangat memuaskan di mana hampir setengah $(27,3 \%)$ dari alumni mengalami kecemasan ringan.

Berdasarkan tabel 2 menunjukkan bahwa hampir seluruh $(78,18 \%)$ responden memiliki prestasi akademik sangat memuaskan, dan sebagian kecil $(21,82 \%)$ alumni memiliki prestasi akademik terpuji. Dari data tersebut tidak ditemukan satupun prestasi akademik alumni dengan predikat memuaskan. Hal ini menunjukkan bahwa prestasi akademik yang dimiliki alumni sudah baik.

Berdasarkan data di atas dapat dikatakan bahwa prestasi akademik dipengaruhi oleh beberapa faktor, di antaranya faktor dari dalam diri individu itu sendiri dan faktor dari luar.Untuk faktor dalam diri individu meliputi kondisi fisik dan psikologis, dan faktor dari luar meliputi faktor lingkungan. Salah satu contoh faktor internal yang berpengaruh terhadap prestasi belajar yaitu adanya gangguan kecemasan.

Berdasarkan tabel 3 tentang prestasi akademik terhadap 55 responden, didapatkan hasil 8 alumni perempuan berpredikat terpuji dan 24 alumni perempuan berpredikat memuaskan. Sedangkan pada alumni laki-laki didapatkan hasil 4 responden berpredikat terpuji, dan 19 alumni laki-laki lainnya berpredikat memuaskan.Dari peneltian ini dapat disimpulkan bahwa perempuan memiliki prestasi yang lebih baik daripada laki-laki.

Tabel 3 juga menunjukkan hasil hampir setengah (36,36\%) alumni mengalami kecemasan sedang dan sebagian kecil $(10,91 \%)$ alumni mengalami kecemasan berat.

Berdasarkan data di atas kecemasan dapat disebabkan karena beberapa hal di antaranya pengalaman masa lalu tidak lulus UKNI, beban apabila tidak lulus UKNI, beban institusi, kurang mendalami soal-soal UKNI, dan kurangnya kurangnya persiapan.

Hal ini sejalan dengan teori yang dikemukakan oleh Stuart \& Sudeen (n Pamungkas, Gunawan, 2011) menyatakan bahwa ada beberapa teori yang telah dikembangkan untuk menjelaskan faktor-faktor yang mempengaruhi kecemasan, diantaranya faktor predisposisi dan faktor presipitasi. Faktor predisposisi meliputi 
teori psikoanalitik, teori interpersonal, teori perilaku, teori keluarga, kajian biologis.Sedangkan faktor presipitasi meliputi faktor internal dan eksternal.

Sedangkan data kecemasan menurut jenis kelamin yang dialami laki-laki lebih tinggi daripada kecemasan yang dialami perempuan. Alumni laki-laki yang mengalami cemas sedang sebanyak 11 orang sedangkan pada alumni perempuan yang mengalami cemas sedang sebanyak 9 orang. Sedangkan pada kategori cemas berat, dialami oleh 4 alumni laki-laki dan 2 alumni perempuan.

Berdasarkan data diatas dapat disimpulkan bahwa sebenarnya jenis kelamin pada dasarnya tidak terlalu berpengaruh dalam terjadinya gangguan kecemasan. Kemungkinan terjadinya gangguan kecemasan pada pria sama dengan wanita.

Hal ini sesuai dengan teori yang dikemukakan oleh Kaplan (2008), bahwa kecemasan merupakan suatu penyerta yang normal dari pertumbuhan, perubahan, pengalaman dari sesuatu yang baru dan belum pernah dicoba, dan dari penemuan identitas sendiri serta arti hidup. Di dalam bukunya yang berjudul Sinopsis Psikiatri mereka menyebutkan bahwa kecemasan berpengaruh pada organ viseral dan motorik, selain itu juga mempengaruhi pikiran, persepsi, dan pembelajaran.

Hasil penelitian ini menunjukkan bahwa hampir seluruh $(78,18 \%)$ alumni memiliki prestasi akademik sangat memuaskan, di mana hampir setengah $(27,3 \%)$ dari alumni mengalami kecemasan sedang. Dan sebagian kecil $(21,81 \%)$ alumni memiliki prestasi akademik terpuji, di mana sebagian kecil $(1,8 \%)$ dari alumni mengalami kecemasan berat.

Hal ini bermakna bahwa kecemasan yang dimiliki alumni berada pada kisaran rerata atau tidak rendah dan tidak tinggi pula. Hasil penelitian didapatkan meskipun kecemasan alumni berada pada kode rerata namun memberikan kontribusi terhadap pelaksanaan uji kompetensi ners yang akan dijalaninya. Dengan demikian dapat dikatakan bahwa ada faktor lain yang menunjang pelaksanaan uji kompetensi yang akan dijalani alumni, di antaranya kemauan belajar, lingkungan, maupun kecemasan yang dialami setiap alumni dalam menghadapi uji kompetensi Ners.

Berdasarkan hasil uji statistik menggunakan Spearman Rank didapatkan nilai $\mathrm{p}=0,866$ di mana $\mathrm{p}>0,05$. Maka $\mathrm{H}_{0}$ diterima, artinya tidak ada hubungan prestasi akademik dengan kecemasan alumni dalam menghadapi uji kompetensi Ners di Stikes Muhammadiyah Lamongan.

Dengan demikian dapat disimpulkan bahwa kecemasan yang di alami alumni mungkin tidak di sebabkan karena hsail prestasi akademik yang didapatkannya, tetapi mungkin terdapat faktor lain yang mempengaruhi kecemasan itu sendiri. Salah satu faktornya prestasi akademik yang didapat diperoleh mahasiswa bukan dari nilai asli setelah mengikuti tes, tetapi hasil yang didapat dalam mengikuti ujian perbaikan atau semester pendek yang diberikan oleh institusi. Karena beberapa studi menunjukkan bahwa mahasiswa yang menerima ujian perbaiakn atau semester pendek menganggap hal itu sebagai sesuatu yang menolongnya dalam meningkatkan prestasi akademik. Sehingga mahasiswa yang 
kurang baik dalam prestasi akademiknya akan mendapatkan nilai standart yang ditetapkan oleh institusi yaitu sangat memuaskan.

Faktor lain diantaranya kesiapan alumni dalam mengerjakan soal-soal ujian, apakah pada saat ujian mahasiswa dalam kondisi sehat atau sedang sakit, sedang memiliki masalah lain atau tidak, tipe dari soal ujian, apakah soal ujian termasuk soal yang menuntut daya ingat atau merupakan soal yang menuntut mahasiswa melakukan analisa yang lebih dalam. sehingga pada saat di lakukan uji statistik pada variabel prestasi akademik dengan variabel kecemasan alumni dalam menghadapi uji kompetensi Ners di STIKes Muhammadiyah Lamongan tidak menunjukkan adanya hubungan yang bermakna. Selain itu alumni yang mengikuti UKNI telah beberapa kali mengikutu tes sehingga alumni telah mempunyai gambaran dalam mengikuti UKNI dan dapat mengontrol kecemasannya.

\section{KESIMPULAN DAN SARAN}

Dari hasil penelitian ini dapat disimpulkan bahwa :

1. Hampir seluruh alumni yang akan mengikuti uji kompetensi Ners di STIKes Muhammadiyah Lamongan memiliki prestasi akademik sangat memuaskan.

2. Hampir setengah alumni yang akan mengikuti uji kompetensi Ners di STIKes Muhammadiyah Lamongan mengalami kecemasan sedang.

3. Tidak ada hubungan prestasi akademik dengan kecemasan alumni dalam menghadapi uji kompetensi Ners di STIKes Muhammadiyah Lamongan.

Selanjutnya peneliti berharap bahwa penelitian dapat menjadi masukan bagi para pendidik untuk mengetahui kecemasan alumni sarjana keperawatan dalam menghadapi uji kompetensi Ners. Penelitian ini dapat menjadi masukan bagi para mahasiswa untuk mengetahui respon yang biasanya muncul saat melaksanakan ujian dan bisa lebih mempersiapkan diri ketika akan menghadapi uji kompetensi Ners.

\section{DAFTAR PUSTAKA}

Adiwidya, V. (2015). Panduan Lulus UKNI (Uji Kompetensi Ners Indonesia) Langkah Mudah Lolos Tes Profesi Keperawatan. Jakarta: Visi Media Pustaka.

Goff, (2011). Stressors, academic performance, and learned resourcefulness baccalaureate nursing student. International Journal of Nursing EducationScholarship 8, Article 1.

Kaplan \& Sadock. (2008). Sinopsis Psikiatri Klinis. Jakarta: Bina Rupa Aksara 
Peran dan Tanggung Jawab Tenaga Kesehatan dalam Mendukung Program Kesehatan

Pamungkas, Gunawan. (2011). Konsep Kecemasan http://.www.teorikecemasan.blogspot.com.diakses pada tanggal 30 Maret 2018.

Setiadi. (2013). Konsep dan Praktek Penulisan Riset Keperawatan Edisi 2. yogyakarta: Graha Ilmu

Townsend, C.M. (2005). PsychiatricMental Healt Nursing : Concepts of Care.Fourth Edition. Philadelphia: Davis Company 